\title{
Vegetation-Environmental Variable Relationships in Ponds of Various Origins along an Altitudinal Gradient
}

\author{
Judita Kochjarová1,, Milan Novikmec ${ }^{3}$, Helena Ot'ahel'ová2, \\ Ladislav Hamerlík ${ }^{4,5}$, Marek Svitok ${ }^{3}$, Matúš Hrivnák ${ }^{1}$, Dušan Senko ${ }^{2}$, \\ Kateřina Bubíková ${ }^{2}$, Zuzana Matúšová ${ }^{3}$, Peter Pal'ove-Balang, \\ Richard Hrivnák ${ }^{2 *}$ \\ ${ }^{1}$ Department of Phytology, Faculty of Forestry, Technical University in Zvolen, \\ T. G. Masaryka 24, SK-96053 Zvolen, Slovakia \\ ${ }^{2}$ Institute of Botany, Slovak Academy of Sciences, Dúbravská cesta 9, SK-84523 Bratislava, Slovakia \\ ${ }^{3}$ Department of Biology and General Ecology, Technical University in Zvolen, \\ T. G. Masaryka 24, SK-96053 Zvolen, Slovakia \\ ${ }^{4}$ Institute of Geological Sciences, Polish Academy of Sciences, \\ Twarda 51/55, 00-818 Warsaw, Poland \\ ${ }^{5}$ Department of Biology and Ecology, Matej Bel University, \\ Tajovského 40, SK-97401 Banská Bystrica, Slovakia \\ ${ }^{6}$ Institute of Biological and Ecological Sciences, P. J. Šafárik University in Košice, \\ Mánesova 23, SK-040 01 Košice, Slovakia
}

Received: 21 October 2016

Accepted: 29 December 2016

\begin{abstract}
Aquatic vegetation of the mountains and sub-alpine ponds in the Tatra Mountains and adjacent area (Slovakia) has been studied with the aim to provide information about the composition and species richness of macrophytes in relation to environmental factors. Macrophytes were studied in two pond groups: natural ponds of glacial origin and artificial ponds. Simultaneously, eight environmental variables were measured or estimated at each pond. The studied pond groups differed significantly (Mann-Whitney U-test, $\mathrm{P}<0.01$ ) in almost all recorded environmental variables except for water temperature and pond area. Almost all environmental characteristics showed higher variability in the artificial ponds. In total, 70 macrophyte taxa were found at the study sites consisting of ca $90 \%$ of vascular plants and ca $10 \%$ of bryophytes. Artificial ponds were characterised by a multi-element vascular plant species group typical for marshy and aquatic habitats of lower altitudes, while Carex rostrata was the only species typical for natural ponds. Species richness differed significantly between the two pond groups, with artificial ponds hosting considerably more species. Species richness of all studied ponds was negatively correlated with altitude and precipitation;
\end{abstract}

*e-mail: richard.hrivnak@savba.sk 
a positive relationship was found with water $\mathrm{pH}$ and conductivity, air temperature, and degree of human impact. The species composition of ponds was affected mainly by precipitation and human impact.

Keywords: macrophytes, mountain region, species diversity, plant assemblage, ponds

\section{Introduction}

High-altitude lentic ecosystems have high ecological and environmental value, support unique plant and animal communities, and are regarded as excellent sensors of environmental change for the entire mountain ecosystem $[1,2]$. Moreover, these biotopes allow us to study diverse adaptations of organisms to variable climatic conditions and anthropogenic effects on their natural environment.

Despite their small size, ponds contribute markedly to local and regional aquatic biodiversity $[3,4]$ and often harbour many rare or endangered species [5]. Understanding the patterns of biodiversity distribution in these ecosystems is essential for any conservation strategies aiming to maintain or enhance their biodiversity [6].

Altitude as a surrogate for several, often co-varying, factors is considered to be the most important variable shaping ecosystems in mountain areas. Duration of ice and snow cover and water temperature are strongly controlled by air temperature. Altitude and related climatic factors are the strongest predictors of both species richness and community composition [7-9]. It is generally known that macrophyte richness decreases with increasing altitude [7]. In addition, sets of various environmental factors include human impact influence aquatic plants in freshwater ecosystems [7]. For example, macrophyte richness is higher in habitats ranging from mesotrophy to eutrophy and lower in nutrient-poor oligotrophic, dystrophic, and nutrient-rich hypereutrophic waterbodies. Mentioned climatic and trophic factors are crucial for changes in macrophyte richness and composition along the altitudinal gradient [7].

So far, only little attention has been paid to plant distribution and species composition of the aquatic vegetation in high-altitude lakes across Europe. Even though several regional studies from particular mountain lakes have been published recently [10-13], there is still much that remains open for study.

Lakes and ponds of the Tatra Mountains (Slovakia, Poland) have become the focus of an intense multidisciplinary long research period. For example, diatoms and macro invertebrates have been studied as indicators of environmental changes in Tatra lakes and ponds [4, 14-15]. The algal flora of the Tatra lakes, both in Slovakia and Poland, has also been comprehensively studied for decades [16-17]. At the same time, only marginal attention has been paid to the aquatic vegetation of vascular plants [18], and current knowledge on the distribution and species-composition of macrophyte vegetation in the area is still insufficient. Furthermore, knowledge about the vegetation of ponds in the Tatra foothills is completely absent.
Lakes and ponds in the Tatra Mountains have different origins. Natural standing waters are of glacial origin and they are distributed across almost the whole altitudinal gradient but dominate at higher elevations, while artificial ponds prevail at lower altitudes. Natural water bodies in lower and moderate altitudes such as river oxbows or shallow temporary ponds usually show higher macrophyte diversity $[19,20]$ than oligotrophic lakes at high-altitude [7]. In addition, artificial ponds are often considered species-poor habitats [21]. On the other hand, it is not a general pattern and, for example, Linton and Goulder [22] reported rich macrophyte assemblages of artificial water bodies.

Our study aims to (i) characterise the composition and richness of aquatic plant communities of all studied ponds and in two groups, natural and artificial mountain and sub-alpine ponds, (ii) identify the main ecological factors determining both macrophyte composition and richness, and (iii) compare community characteristics between natural and artificial sites. We hypothesised that natural sub-alpine ponds will have lower species richness compared to artificial mountain ponds. Similarly, we expected different species composition for these two pond groups.

\section{Material and Methods}

\section{Study Area and Sampling Sites}

Macrophytes were studied in 24 natural and artificial ponds (Fig. 1) in the Tatras, including the Western and High Tatra Mountains, their foothills, and adjacent basins (Liptovská kotlina basin, Popradská kotlina basin, Levočské vrchy Mountains, and Spišská Magura Mountains). The ponds of different origins and levels of human impact were distributed across an altitudinal gradient from the sub-mountain to sub-alpine belt. Only ponds with the presence of macrophytes were selected as study sites based on foregoing knowledge.

The Tatra Mountains are situated along the border between Slovakia and Poland (in the Western Carpathians; $20^{\circ} 10^{\prime} \mathrm{E}$ and $49^{\circ} 10^{\prime} \mathrm{N}$ ). For a general description of the relevant hydrology, soil, and vegetation attributes of the Tatra Mountains see Kopáček et al. [23]. There are more than 140 permanent natural lakes of Quaternary glacial origin in the Tatras. Most of them are situated above the treeline in the sub-alpine and alpine zones. They span a wide range of environmental conditions with respect to altitude, depth, surface-area, and watershed characteristics $[24,25]$. However, macrophytes have developed only in lakes and ponds situated at lower altitudes in the spruce forest vegetation zone (Piceetea excelsae Klika 1948 


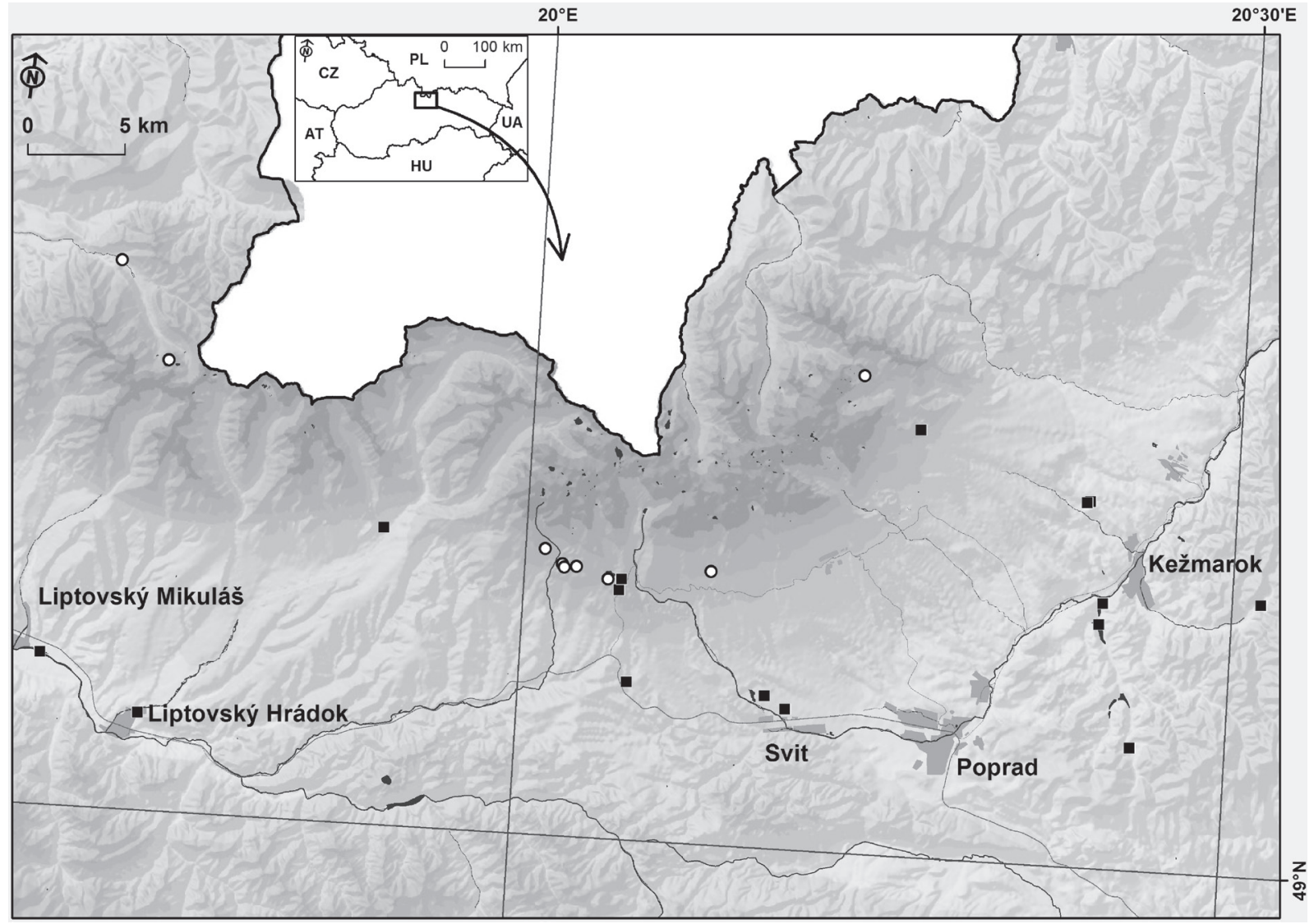

Fig. 1. Locations of the artificial (black squares) and natural (white circles) ponds surveyed.

class) and sub-alpine dwarf pine vegetation zone (Roso pendulinae-Pinetea mugo Theurillat in Theurillat et al. 1995 class), between ca 1,220 and 1,650 m a.s.l. For our study, nine natural ponds were selected.

Artificial ponds of the study area are represented mainly by gravel pits and dammed ponds located at the SW-SE foothills of the Tatras. Gravel pits originated due to surface mining of construction gravel and sand material (the sites are located in the alluvia of Váh and Poprad rivers at 590-750 $\mathrm{m}$ a.s.1). Dammed ponds were built mainly for recreation, fishery, and water supply (the sites are located between 630 and 1,335 $\mathrm{m}$ a.s.l.). In total we studied 15 artificial ponds.

The studied ponds occur in the area of relatively cold climate and moderate-to-high total annual precipitation in the context of the Central European landscape. They occupy broad altitudinal range and vary in water environmental variables. Pond area is the most varying characteristic; altitude and climatic variables had relatively broad ranges as well. Among physical-chemical variables, water conductivity was the most variable, showing very poor to moderate soluble mineral content (Table 1).

\section{Field Sampling}

All macrophyte species including bryophytes and vascular plants were recorded within each studied pond during the summer of 2012-14. Macrophyte presence was determined in the whole area of ponds by wading in shallow water or using a boat where necessary. Species richness was evaluated as a number of observed species. Nomenclature of taxa follows the Slovak checklist [26]. Categorization of aquatic plants and helophytes follows Willby et al. [27] and Kolada [28], respectively. Simultaneously, environmental variables were measured or estimated at each studied pond (Table 1). Altitude was determined by Garmin GPS map 62, and water temperature, $\mathrm{pH}$, and conductivity were measured by a CyberScan PC 650. These characteristics were measured at three places in each pond at a depth of $20 \mathrm{~cm}$ under the water surface within two weeks in August 2014 with relatively stable weather. For analysis, the mean value of the three measurements was used. Pond area of each study site was evaluated using Google Earth by QGIS (qgis. org/en/docs/index.html). Climatic data (mean annual air temperature and total annual precipitation) were derived from raster values, which were extracted from the Geographic Resource Analysis Support System (GRASS) of the Geographic Information System (GIS) environment (ver. 7.1) released under the GNU/GPL licence. These data were computed from rasters of climatic data for the period 1961-90 provided by the Slovak Hydrometeorological Institute. Human impact was evaluated at three levels based on our expert knowledge: 1 - none or very low, 2 - moderate, and 3 - strong. 
Table 1. Basic environmental characteristics and species richness of the studied ponds.

\begin{tabular}{|c|c|c|c|c|c|c|c|c|c|c|}
\hline Sampling site & $\begin{array}{l}\text { Pond } \\
\text { origin }\end{array}$ & $\begin{array}{l}\text { Altitude } \\
\text { (m) }\end{array}$ & $\begin{array}{l}\text { Water } \\
\text { tempe- } \\
\text { rature } \\
\left({ }^{\circ} \mathrm{C}\right)\end{array}$ & $\begin{array}{c}\text { Water } \\
\mathrm{pH}\end{array}$ & $\begin{array}{l}\text { Water } \\
\text { condu- } \\
\text { ctivity } \\
(\mu \mathrm{S} / \mathrm{cm})\end{array}$ & $\begin{array}{c}\text { Mean } \\
\text { annual } \\
\text { air tempe- } \\
\text { rature }\left({ }^{\circ} \mathrm{C}\right)\end{array}$ & $\begin{array}{c}\text { Total } \\
\text { annual } \\
\text { precipitation } \\
(\mathrm{mm})\end{array}$ & $\begin{array}{l}\text { Pond } \\
\text { area } \\
\left(\mathrm{m}^{2}\right)\end{array}$ & $\begin{array}{l}\text { Human } \\
\text { impact }\end{array}$ & $\begin{array}{l}\text { Num- } \\
\text { ber of } \\
\text { species }\end{array}$ \\
\hline Okoličné & 0 & 594 & 24.9 & 8.71 & 152 & 6.7 & 716 & 16,714 & 3 & 11 \\
\hline Žakovce1 & 0 & 630 & 15.2 & 4.84 & 945 & 6.1 & 615 & 70,331 & 3 & 13 \\
\hline Žakovce2 & 0 & 630 & 20.4 & 7.76 & 567 & 6.1 & 621 & 193,820 & 3 & 4 \\
\hline Beliansky rybník & 0 & 652 & 21.0 & 6.92 & 231 & 5.8 & 662 & 60 & 2 & 7 \\
\hline Liptovský Hrádok & 0 & 655 & 18.0 & 8.70 & 226 & 6.2 & 766 & 3,599 & 3 & 2 \\
\hline Mlynčeky2 & 0 & 668 & 19.6 & 8.27 & 118 & 6.0 & 656 & 20,209 & 2 & 18 \\
\hline Mlynčeky1 & 0 & 676 & 20.7 & 7.79 & 119 & 6.0 & 661 & 21,318 & 2 & 26 \\
\hline L'ubica & 0 & 680 & 21.3 & 8.30 & 211 & 5.9 & 655 & 1,221 & 2 & 3 \\
\hline Vlková & 0 & 680 & 16.5 & 7.18 & 840 & 6.0 & 644 & 377 & 2 & 2 \\
\hline Batizovce1 & 0 & 750 & 25.6 & 8.73 & 160 & 5.8 & 699 & 717 & 3 & 14 \\
\hline Batizovce2 & 0 & 750 & 19.6 & 8.25 & 284 & 5.9 & 682 & 32,548 & 3 & 11 \\
\hline Stredný mlyn & 0 & 855 & 18.0 & 7.50 & 101 & 5.5 & 797 & 21,799 & 2 & 9 \\
\hline Podbanské & 0 & 918 & 11.7 & 7.60 & 79 & 5.1 & 940 & 524 & 2 & 6 \\
\hline Zverovka & 1 & 983 & 20.8 & 6.45 & 21 & 4.7 & 1,165 & 2,315 & 1 & 3 \\
\hline $\begin{array}{l}\text { Čierne pleso pri } \\
\text { Vyšných Hágoch }\end{array}$ & 1 & 1,219 & 18.7 & 5.83 & 19 & 4.1 & 1,222 & 85 & 1 & 7 \\
\hline $\begin{array}{c}\text { Nižné Rakytovské } \\
\text { pleso }\end{array}$ & 1 & 1,308 & 11.7 & 5.20 & 20 & 4.0 & 1,315 & 821 & 1 & 1 \\
\hline $\begin{array}{c}\text { Vyšné } \\
\text { Rakytovské pleso }\end{array}$ & 1 & 1,308 & 24.6 & 5.60 & 8 & 3.9 & 1,346 & 1,876 & 1 & 1 \\
\hline $\begin{array}{l}\text { Nové Štrbské } \\
\text { pleso }\end{array}$ & 0 & 1,318 & 16.0 & 6.82 & 45 & 3.9 & 1,314 & 18,635 & 2 & 3 \\
\hline $\begin{array}{l}\text { Jozef Szentiványi } \\
\text { pond }\end{array}$ & 0 & 1,335 & 7.8 & 7.60 & 26 & 3.8 & 1,345 & 781 & 2 & 3 \\
\hline Štrbské pleso & 1 & 1,351 & 14.9 & 7.55 & 27 & 3.8 & 1,363 & 189,959 & 2 & 2 \\
\hline $\begin{array}{l}\text { Smrekovické } \\
\text { pliesko }\end{array}$ & 1 & 1,369 & 24.8 & 5.40 & 15 & 3.7 & 1,375 & 542 & 1 & 1 \\
\hline Jamské pleso & 1 & 1,448 & 15.8 & 5.90 & 14 & 3.2 & 1,478 & 5790 & 1 & 1 \\
\hline Biele pleso & 1 & 1,612 & 15.0 & 7.00 & 31 & 2.4 & 1,570 & 8186 & 1 & 2 \\
\hline $\begin{array}{c}\text { Stredné Roháčske } \\
\text { pleso }\end{array}$ & 1 & 1,650 & 14.4 & 6.50 & 18 & 1.3 & 1,782 & 1931 & 1 & 1 \\
\hline All ponds: Mean & & 1,101 & 18.2 & 7.1 & 178 & 4.8 & 1,016 & 25,589 & 1.9 & 6.3 \\
\hline (Min.-Max.) & & $(594-1,650)$ & $(7.8-25.6)$ & $(4.8-8.7)$ & $(8-945)$ & $(1.3-6.7)$ & $(615-1,752)$ & $(60-193,820)$ & $(1-3)$ & $(1-26)$ \\
\hline $\begin{array}{l}\text { Artificial ponds: } \\
\text { Mean }\end{array}$ & . & 786 & 18.4 & 7.7 & 274 & 5.7 & 785 & 26,844 & 2.4 & 8.8 \\
\hline (Min.-Max.) & & $(594-1,335)$ & $(7.8-25.6)$ & $(4.8-8.7)$ & $(26-945)$ & $(3.8-6.7)$ & $(615-1,345)$ & $(60-193,820)$ & $(2-3)$ & $(2-26)$ \\
\hline $\begin{array}{c}\text { Natural ponds: } \\
\text { Mean }\end{array}$ & . & 1,360 & 17.9 & 6.2 & 19 & 3.5 & 1,401 & 23,501 & 1.1 & 2.1 \\
\hline (Min.-Max.) & & $(983-1,650)$ & $(11.7-24.8)$ & $(5.2-7.6)$ & $(8-31)$ & $(1.3-4.7)$ & $(1,165-1,782)$ & $(85-189,959)$ & $(1-2)$ & $(1-7)$ \\
\hline U-value & . & 8.0 & 54.5 & 15.0 & 2.0 & 7.0 & 5.0 & 55.0 & 4.5 & 9.5 \\
\hline P-value & . & $* * *$ & ns & $* *$ & $* * *$ & $* * *$ & $* * *$ & ns & $* * *$ & $* * *$ \\
\hline
\end{tabular}

Pond origin: 0 - artificial, 1 - natural. Human impact: 1 - none or very low, 2 - moderate, and 3 - strong. The assessed variables were compared between the man-made and natural ponds using the Mann-Whitney U-test (ns = non-significant,

$* \mathrm{P}<0.05, * * \mathrm{P}<0.01, * * * \mathrm{P}<0.001)$. 


\section{Data Analysis}

Correlations (Spearman rank correlation) among studied environmental variables (Fig. 2) and between variables and species richness were calculated using $\mathrm{R}$ [29]. Subsequently, from the three strongly correlated (Spearman $\rho>0.9, \mathrm{P}<0.001$ ) variables (altitude, mean annual air temperature, and total annual precipitation) only precipitation was selected and used in the ordination analysis. canonical correspondence analysis (CCA) was used to determine the species composition-environmental pattern. Presence/absence data were used, rare species were down-weighted, and one outlier (Lake Stredné Roháčske pleso with the unique species Sparganium angustifolium) was omitted from final analysis. CANOCO 5.0 for Windows package [30] was used for ordination analysis.
Differences in environmental variables between the natural and artificial ponds were tested using the MannWhitney $U$-test in STATISTICA software [31]. Species unique for the two groups were identified according to the concept of fidelity measuring the species concentration in given units [32]. The following thresholds were given: $p h i$ coefficient $\geq 30$, minimal frequency within group $20 \%$, and differences between groups in frequency more than $50 \%$.

\section{Results}

\section{Species Richness and Composition}

Sampling of studied ponds yielded a total of 70 macrophyte plant taxa, almost $90 \%$ of which were vascular plants and ca $10 \%$ were bryophytes. More than $24 \%$ of the $\begin{array}{llll}10 & 15 & 20 & 25\end{array}$
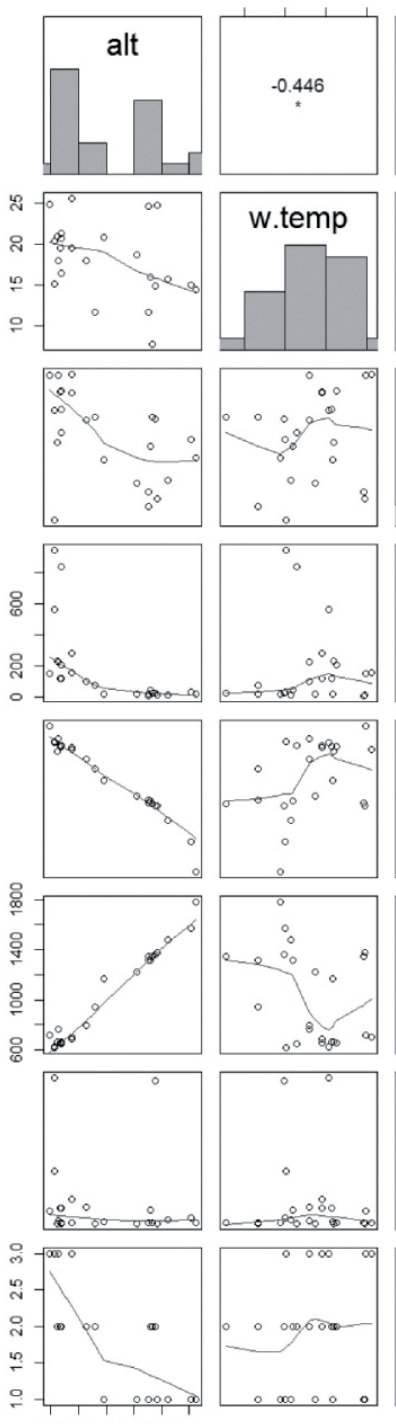

$600 \quad 1000 \quad 1400$

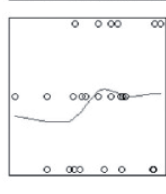

$0200 \quad 600$
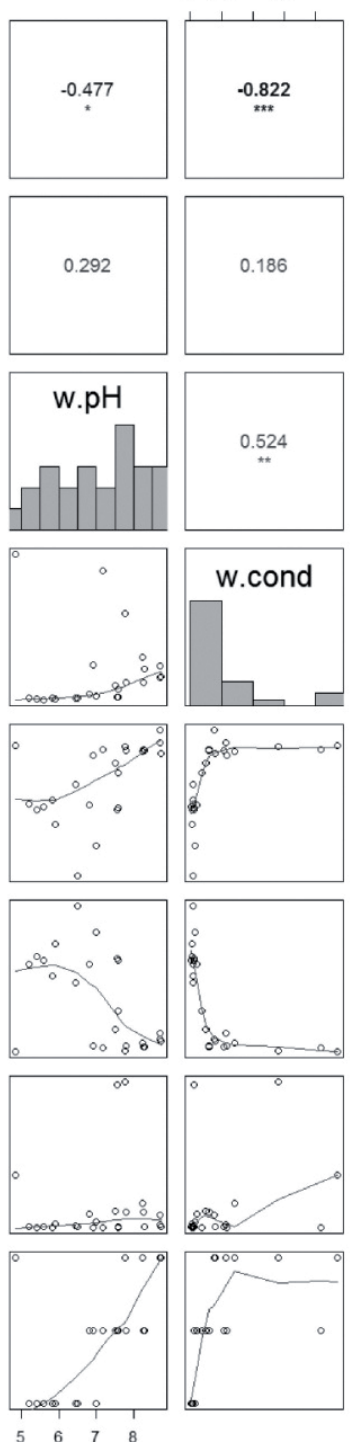
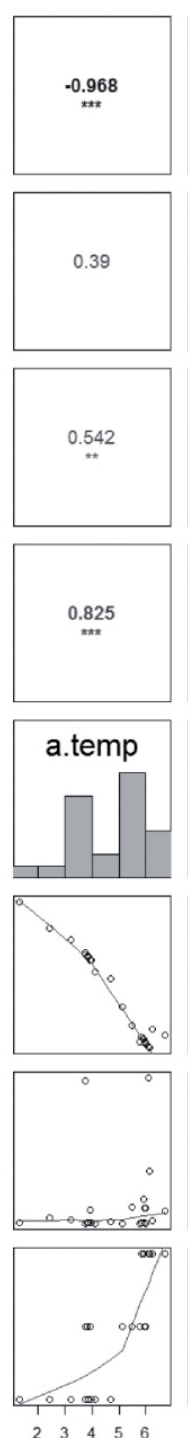

$600 \quad 1000 \quad 1400 \quad 1800$
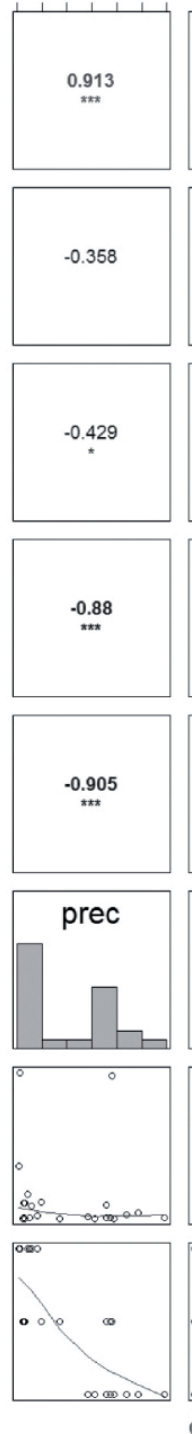

$\begin{array}{lllll}1.0 & 1.5 & 2.0 & 2.5 & 3.0\end{array}$
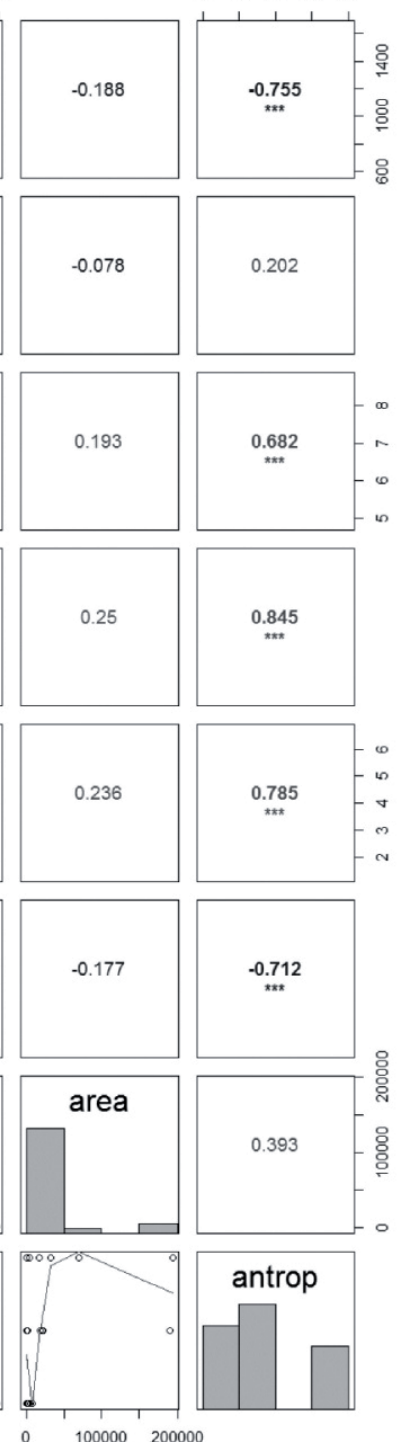

Fig. 2. Correlations between studied environmental variables.

Legend: alt - altitude, w.temp - water temperature, w.ph - water $\mathrm{pH}$, w.cond - water conductivity, a.temp - mean annual air temperature, prec - total annual precipitation, area - pond area, antrop - human impact; line in left side graph - LOWESS (locally weighted scatterplot smoothing). The most significant positive correlations are bold. Significance: $\left.{ }^{*} \mathrm{p}<0.05, * * \mathrm{p}<0.01, * * * \mathrm{p}<0.001\right)$. 
taxa recorded were aquatic plants and the rest consisted of emergent helophytes and hygrophilous species. Species richness varied from 1 to 26 taxa per site and the mean taxa number was higher in artificial ponds (Table 1). The shift of community composition from species such as Juncus effusus, Myriophyllum spicatum, Persicaria amphibia, Phragmites australis, and Potamogeton pectinatus to Carex rostrata, Glyceria notata, or Scirpus sylvaticus is obvious along the first CCA ordination axis (Fig. 3a).

\section{Effect of Environmental Variables on Macrophyte Vegetation}

Species richness of studied ponds was significantly correlated $(p<0.05)$ with all but two environmental variables, pond area (Spearman $\rho=0.27$ ) and water temperature (0.29). Negative correlations were detected with altitude (Spearman $\rho=-0.68$ ) and precipitation $(-0.69)$, and positive response was found with water $\mathrm{pH}$ $(0.54)$ and conductivity $(0.63)$, air temperature $(0.65)$, and degree of human impact $(0.67)$.
Species composition was related mainly to precipitation (weighted correlation with the first CCA axis $=0.95$ ) followed by degree of human impact (-0.73). Second CCA axis is most correlated with water conductivity and pond area (both 0.36), but these relationships were relatively weak (Fig. 3b). Environmental variables explained 36.9\% of the total variation in community data.

\section{Characteristic Features of Natural and Artificial Ponds}

The two compared pond groups were relatively well separated when only two artificial ponds located at higher altitudes showed more similar composition to natural ponds than to the artificial ones (Fig. 3b). While artificial ponds were characterised by the presence of unique species typical for marshy and aquatic habitats of lower altitudes (Sparganium erectum, Typha latifolia, Myriophyllum spicatum, Lemna minor, Eleocharis palustris, Alisma plantago-aquatica, Phragmites australis, Potamogeton pusillus agg., and Potamogeton natans), the single species characteristic for natural ponds was Carex rostrata.
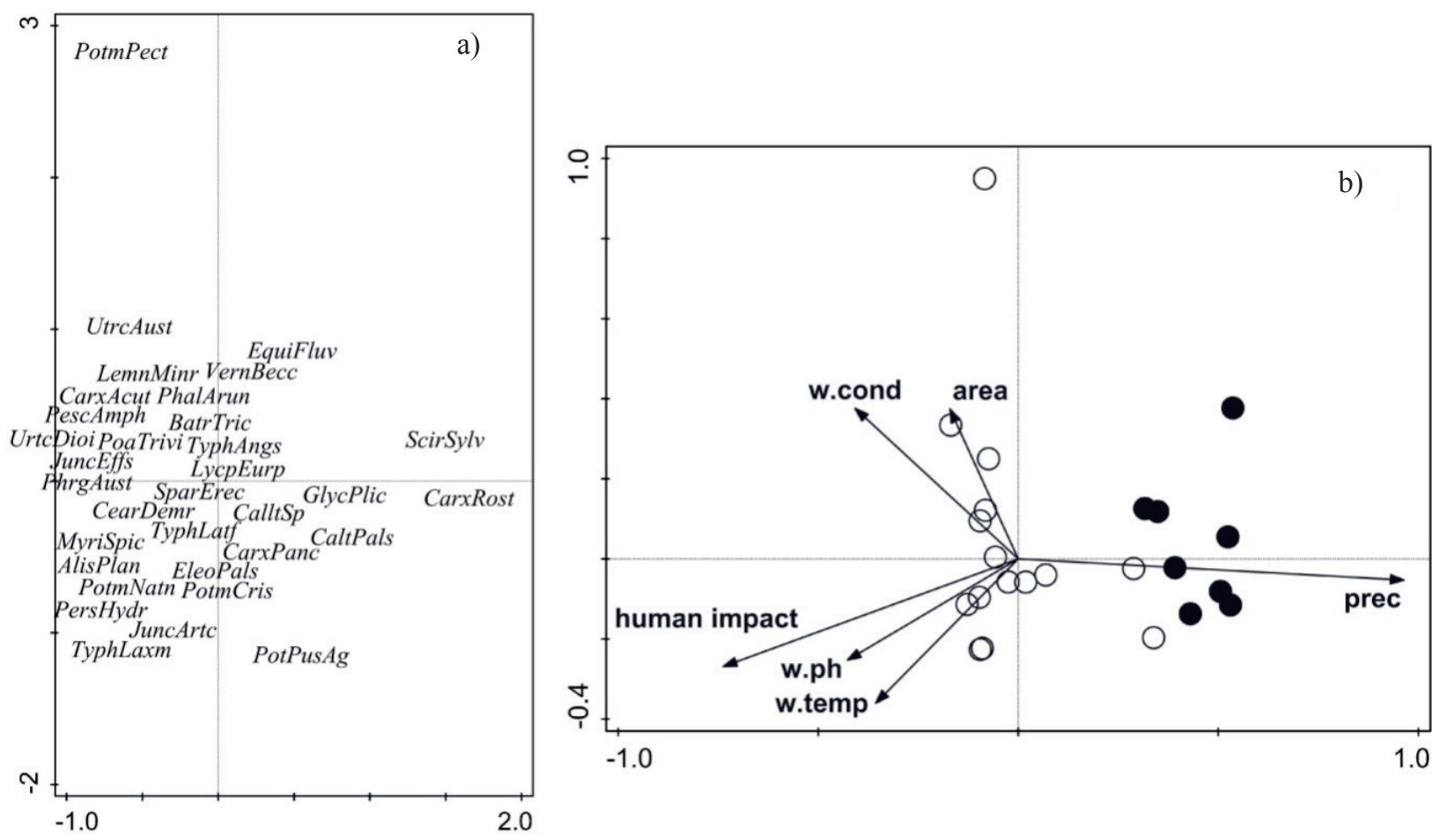

Fig. 3. Ordination diagram (CCA) of species a), sampling site, and environmental characteristics b). Total inertia was 6.153, eigenvalues of the first and second CCA axis were 0.756 and 0.554 , respectively.

Legend: Black circles - natural ponds, white circles - artificial ponds

Only species with occurrence in two and more ponds are displayed.

AlisPlan - Alisma plantago-aquatica, BatrTric - Batrachium trichophyllum, CalltSp - Callitriche sp., CaltPals - Caltha palustris, CarxAcut - Carex acutiformis, CarxPanc - Carex paniculata, CarxRost - Carex rostrata, CearDemr - Ceratophyllum demersum, EleoPals - Eleocharis palustris, EquiFluv - Equisetum fluviatile, GlycPlic - Glyceria notata, JuncArtc - Juncus articulatus, JuncEffs Juncus effusus, LemnMinr - Lemna minor, LycpEurp - Lycopus europaeus, MyriSpic-Myriophyllum spicatum, PescAmph - Persicaria amphibia, PersHydr - Persicaria hydropiper, PhalArun - Phalaroides arundinacea, PhrgAust-Phragmites australis, PoaTrivi - Poa trivialis, PotmCris - Potamogeton crispus, PotmNatn - Potamogeton natans, PotmPect - Potamogeton pectinatus, PotPusAg - Potamogeton pusillus agg., ScirSylv - Scirpus sylvaticus, SparErec - Sparganium erectum, TyphAngs - Typha angustifolia, TyphLatf - Typha latifolia, TyphLaxm - Typha laxmannii, UrtcDioi - Urtica dioica, UtrcAust - Utricularia australis, VernBecc - Veronica beccabunga. For abbreviations of environmental variables see Fig. 2. 
Species richness differed significantly between the two pond groups $(p=0.001)$, and artificial ponds hosted more species on average. Except for water temperature and pond area, environmental variables differed significantly between the two groups of ponds (Table 1).

\section{Discussion}

Species Richness and Composition and Their Relation to Environmental Factors

Macrophyte species richness of the natural ponds was very low (two taxa per pond on average), while that of artificial ponds was several fold higher (almost nine on average). Species richness of the natural ponds was considerably lower than that in natural oligotrophic to mesotrophic lakes in high-mountain systems across Europe, where a much broader spectrum of macrophyte species is known, including several Charophytes and more vascular plants of the genera Potamogeton, Isoëtes, Batrachium, and others [10, 12, 33, 34]. Macrophyte species richness in artificial Tatra ponds is comparable or slightly lower than the richness of pond ecosystems across Europe [35, 36].

The shift of species composition from lowland marshy habitats to hygrophilous plants of moderate to higher altitudes along the first ordination axis is obvious. The composition shift is related to the total annual precipitation and collinear variables (mean annual air temperature, altitude) as well as human impact (Figs 2-3). The position of a substantial part of the macrophyte species in the ordination space was positively related to lower precipitation and altitude, higher air temperature, and human impact, which represents better conditions for macrophytes than those at the opposite end of the environmental gradient. Variability of the species composition captured by the second ordination axis was related mainly to water conductivity and pond area that decreased rapidly with increasing altitude (Fig. 3). Several studies from the mountain regions across Europe showed similar results: high mountain ponds and lakes offer conditions that are too harsh for the development of macrophyte vegetation, and the presence and diversity of macrophytes in these habitats is rare and low, respectively $[11,13]$. Artificial ponds with more appropriate climatic conditions compared to those at high altitudes, intensity of human impact, and subsequently higher nutrient supply can provide convenient space for macrophyte vegetation [7].

\section{Differences between Natural and Artificial Ponds}

As assumed in our hypothesis, species richness of the natural Tatra ponds was considerably lower than that of artificial ponds in the foothills. Species richness was negatively correlated with altitude and related climatic characteristics (air temperature and precipitation), as well as with water $\mathrm{pH}$, conductivity, and human impact. Due to the fact that the majority of natural ponds occur at high altitudes with low or no human impact and all of them are oligotrophic, while artificial ponds are on the opposite end of the gradient, it is likely that mainly natural environmental factors related to altitude are responsible for different species richness of both groups. Our results confirmed that altitude and correlated proximate environmental variables are among the most significant predictors of macrophyte richness $[8,9,13]$.

Besides a few bryophytes (which occurred very sporadically), only one vascular plant species (Carex rostrata) was found regularly in all studied natural ponds. Conversely, nine taxa (four aquatic plants and five helophytes) were found as unique for artificial ponds. The climatic and site conditions of the natural ponds represent a specific environment that is only appropriate for few vascular plant species. Higher air temperature and nutrient content of the water, which is typical for artificial ponds at lower altitudes, provide better life conditions for plants [7]. Human impact and precipitation, strongly correlated with air temperature and altitude, were the most responsible parameters for differentiation of species composition between the two pond types. Similarly to species richness, also species composition of artificial ponds showed higher variability relative to natural ponds. Carex rostrata seems to be common for natural highmountain lakes and ponds in the Western Carpathians, as well as other European mountain ranges [10, 37]. In contrast, the mentioned aquatic and marsh species unique for artificial ponds belong to the plants common in aquatic habitats of lower altitudes of Central Europe [38-43]. Lemna minor, Potamogeton natans, and P. pusillus agg. are aquatic species typical mainly for eutrophic waters [27] and which occurred only in artificial ponds situated at lower altitudes.

\section{Conclusions}

In accordance with our hypotheses, we confirmed that i) species richness of macrophytes decrease along the altitudinal gradient and ii) natural lakes in high altitudes have different species composition compared to artificial ponds in the foothills. The main environmental drivers of vegetation patterns in the studied aquatic habitats were altitude and strongly correlated climatic characteristics (air temperature and precipitation), as well as water conductivity and human impact. The effect of lake origin was, to a large extent, suppressed with the above factors and thus not directly interpretable. Our study showed that artificial ponds with relatively high human impact can host species-rich macrophyte assemblages and they can be important aquatic habitats for preserving macrophytes in higher altitudes. 


\section{Acknowledgements}

This work was supported by the Slovak Research and Development Agency under contract No. APVV-0059-11, and the Science Agency of the Ministry of Education of the Slovak Republic and Slovak Academy of Sciences (VEGA project Nos. 2/0090/12 and 2/0081/13). The Geographic Resources Analysis Support System 364 (GRASS) and some other calculations were done in the Computing Centre of the Slovak Academy of Sciences using the infrastructure acquired within projects ITMS 26230120002 and ITMS 26210120002 (Slovak infrastructure for high-performance computing), supported by the Research and Development Operational Program funded by the ERDF.

\section{References}

1. OERTLI B., INDERMUEHLE N., ANGÉLIBERT S., HINDEN H., STOLL A. Macroinvertebrate assemblages in 25 high alpine ponds of the Swiss National Park (Cirque of Macun) and relation to environmental variables. Hydrobiologia 597 (1), 29, 2008.

2. KERNAN M., VENTURA M., BITUŠÍK P., BRANCELJ A., CLARKE G., VELLE G., RADDUM G.G., STUCHLÍK E., CATALAN J. Regionalisation of remote European mountain lake ecosystems according to their biota: environmental versus geographical patterns. Freshwater Biol. 54 (12), 2470, 2009.

3. NICOLET P., BIGGS J., FOX G., HODSON M.J., REYNOLDS C., WHITFIELD M., WILLIAMS P. The wetland plant and macroinvertebrate assemblages of temporary ponds in England and Wales. Biol. Conserv. 120 (2), 261, 2004.

4. HAMERLÍK L., SVITOK M., NOVIKMEC M., OČADLÍK M., BITUŠÍK P. Local, among-site, and regional diversity patterns of benthic macroinvertebrates in high altitude waterbodies: do ponds differ from lakes? Hydrobiologia $\mathbf{7 2 3}$ (1), 41, 2014.

5. OERTLI B., BIGGS J., CÉRÉGHINO R., GRILlAS P., JOLY P., LACHAVANNE J.B. Conservation and monitoring of pond biodiversity: introduction. Aquat. Conserv. Mar. Freshwater Ecosyst. 15 (6), 535, 2005.

6. MARTÍNEZ-SANZ C., FERNÁNDEZ-ALÁEZ C., GARCÍA-CRIADO F. Richness of littoral macroinvertebrate communities in mountain ponds from NW Spain: what factors does it depend on? J. Limnol. 71 (1), 154, 2012.

7. LACOUL P., FREEDMAN B. Environmental influences on aquatic plants in freshwater ecosystems. Environ. Res. 14, 89, 2006a.

8. LACOUL P., FREEDMAN B. Relationships between aquatic plants and environmental factors along a steep Himalayan altitudinal gradient. Aquat. Bot. 84 (3), 3, 2006b.

9. JONES J.I., LI W., MABERLY S.C. Area, altitude and aquatic plant diversity. Ecography 26 (4), 411, 2003.

10. BLAŽENČIĆ J., BLAŽENČIĆ Ž. Macrophytes of the lakes Trnovačko Jezero, Veliko Stabanjsko Jezero and Malo Stabanjsko Jezero on Mt. Volujak (Montenegro). Arch. Biol. Sci. 57 (3), 213, 2005.

11. HINDEN H., OERTLI B., MENETREY N., SAGER L., LACHAVANNE J.B. Alpine pond biodiversity: what are the related environmental variables? Aquatic Conserv. Mar. Freshwater Ecosyst. 15 (6), 613, 2005.
12. GERM M., SIMČIČ T. Vitality of aquatic plants and microbial activity of sediment in an oligotrophic lake (Lake Bohinj, Slovenia). J. Limnol. 70 (2), 305, 2011.

13. PULIDO C., RIERA J.L., BALLESTEROS E., CHAPPUIS E., GACIA E. Predicting aquatic macrophyte occurrence in soft-water oligotrophic lakes (Pyrenees mountain range). J. Limnol. 74 (1), 143, 2015.

14. KOWNACKI A., GALAS J., DUMNICKA E., MIELEWCZYK S. Invertebrate communities in permanent and temporary high mountain lakes (Tatra Mts). Ann. Limnol. - Int. J. Limn. 36 (3), 181, 2000.

15. KRNO I., ŠPORKA F., GALAS J., HAMERLÍK L., ZAŤOVIČOVÁ Z., BITUŠÍK P. Littoral benthic macroinvertebrates of mountain lakes in the Tatra Mountains (Slovakia, Poland). Biologia 61 (18), 147, 2006.

16. KAWECKA B., GALAS J. Diversity of epilithic diatoms in high mountain lakes under the stress of acidification (Tatra Mountains, Poland). Ann. Limnol. - Int. J. Limn. 39 (3), 239, 2003.

17. ŠTEFKOVÁ E. Epilithic diatoms of mountain lakes of the Tatra Mountains (Slovakia). Biologia 61 (18), 101, 2006.

18. DÍTĚ D., PUKAJOVÁ D., SLIVINSKÝ J. Sparganium angustifolium (Sparganiaceae) - a new locality in the Carpathians. Biologia 59 (4), 491, 2004.

19. RADULOVIĆ S., LAKETIĆ D. TEODOROVIĆ I. A botanical classification of standing waters in Serbia and its application to conservation. Aquat. Conserv. Mar. Freshwater Ecosyst. 21 (6), 510, 2011.

20. LUKÁCS B.A., SRAMKÓ G., MOLNÁR V.A. Plant diversity and conservation value of continental temporary pools. Biol. Conserv. 158, 393, 2013.

21. NOBLE A., HASSALL C. Poor ecological quality of urban ponds in northern England: causes and consequences. Urban Ecosystems 18 (2), 649, 2015.

22. LINTON S., GOULDER R. Botanical conservation value related to origin and management of ponds. Aquat. Conserv. Mar. Freshwat. Ecosyst. 10 (2), 77, 2000.

23. KOPÁČEK J., HARDEKOPF D., MAJER V., PŠENÁKOVÁ P., STUCHLÍK E., VESELÝ J. Response of alpine lakes and soils to changes in acid deposition: the MAGIC model applied to the Tatra Mountain region, Slovakia-Poland. J. Limnol. 63 (1), 143, 2004.

24. GREGOR V., PACL J. Hydrológia tatranských jazier. Acta Hydrol. Slov. 6 (1), 161, 2005.

25. BITUŠÍK P., SVITOK M., KOLOŠTA P., HUBKOVÁ M. Classification of the Tatra Mountain lakes (Slovakia) using chironomids (Diptera, Chironomidae). Biologia 61 (18), 191, 2006.

26. MARHOLD K., HINDÁK F. (Eds). Checklist of nonvascular and vascular plants of Slovakia. Veda, Bratislava, $1,1998$.

27. WILLBY N.J., ABERNETHY V.J., DEMARS B.O.L. Attribute-based classification of European hydrophytes and its relationship to habitat utilization. Freshwater Biol. 43 (1), 43, 2000.

28. KOLADA A. The use of helophytes in assessing eutrophication of temperate lowland lakes: Added value? Aquat. Bot. 129, 44, 2016.

29. R CORE TEAM. R. A language and environment for statistical computing. R Foundation for Statistical Computing, Vienna, 1, 2014.

30. TER BRAAK C.J.F., ŠMILAUER P. CANOCO reference manual and 738 user's guide: software for ordination (version 5.0). Microcomputer Power, Ithaca, NY, 1, 2012.

31. STATSOFT. STATISTICA. System reference. StatSoft Inc., Tulsa, 1, 2001. 
32. CHYTRÝ M., TICHÝ M., HOLT J., BOTTA-DUKÁT Z. Determination of diagnostic species with statistical fidelity measures. J. Veg. Sci. 13 (1), 79, 2002.

33. HEEGAARD E., BIRKS H.H., GIBSON C.E., SMITH S.J., WOLFE-MURPHY S. Species - environmental relationships of aquatic macrophytes in Northern Ireland. Aquat. Bot. 70 (3), 175, 2001.

34. VESIĆ A., BLAŽENČIĆ J., ŠINŽAR-SEKULIĆ J. Ecological preferences of charophytes in Serbia in relation to habitat type and other aquatic macrophytes. Plant Biosyst. 150 (3), 490, 2016.

35. WILLIAMS P., WHITFIELD M., BIGGS J., BRAY S., FOX G., NICOLET P., SEAR D. Comparative biodiversity of rivers, streams, ditches and ponds in an agricultural landscape in Southern England. Biol. Conserv. 115 (2), 329, 2004.

36. DAVIES B., BIGGS J., WILLIAMS P., WHITFIELD M., NICOLET P., SEAR D., BRAY S., MAUND S. Comparative biodiversity of aquatic habitats in the European agricultural landscape. Agric. Ecosyst. Environ. 125 (1-4), 1, 2008.
37. HRIVNÁK R., KOCHJAROVÁ J., OŤAHEL'OVÁ H., DÚBRAVKOVÁ D. An evaluation of aquatic and marsh vegetation occurrence in water reservoirs in the Nízke Tatry Mts 2, 109, 2009.

38. VALACHOVIČ M. (Ed.) Plant communities of Slovakia 3. Wetland Vegetation. Veda, Bratislava, 1, 2001.

39. MATUSZKIEWICZ W. A guide of Poland plant communities. Wydawnictwo Naukowe PWN, Warszawa, 1, 2008.

40. CHYTRÝ M. (Ed). Vegetation of the Czech Republic 3. Aquatic and Wetland Vegetation. Academia, Praha, 1, 2011.

41. BORHIDI A., KEVEY B., LENDVAI G. Plant communities of Hungary. Akadémiai Kiadó, Budapest, 1, 2012.

42. ZELNIK I., POTISEK M., GABERŠČIK A. Ecological preferences of charophytes in Serbia in relation to habitat type and other aquatic macrophytes. Pol. J. Environ. Stud. 21 (6), 1911, 2012.

43. HRIVNÁK R., OŤAHEL'OVÁ H., KOCHJAROVÁ J., PALOVE-BALANG P. Effect of environmental conditions on species composition of macrophytes - study from two distinct biogeographical regions of Central Europe. Knowlg. Managt. Aquatic Ecosyst. 411, 09, 2013. 